\title{
Conservation implications of the apparent mismatch between population dynamics and foraging effort in French northern gannets from the English Channel
}

\author{
David Grémillet ${ }^{1,2, *}$, Lorien Pichegru, ${ }^{1,3}$, François Siorat ${ }^{4}$, Jean-Yves Georges ${ }^{1}$ \\ ${ }^{1}$ Centre National de la Recherche Scientifique, DEPE-IPHC, 23 rue Becquerel, 67087 Strasbourg Cedex 02, France \\ ${ }^{2}$ DST/NRF Centre of Excellence, Percy FitzPatrick Institute, University of Cape Town, 7701 Rondebosch, South Africa \\ ${ }^{3}$ Université Louis Pasteur, 4 rue Blaise Pascal, 67070 Strasbourg, France \\ ${ }^{4}$ Station Ornithologique de l'Ile Grande, Ligue Pour la Protection des Oiseaux, 22560 Pleumeur-Bodou, France
}

\begin{abstract}
Human activities affect all trophic levels of marine food webs and threaten numerous species. The status of such populations can be assessed via monitoring of their size. However, in longlived species such as most marine top predators, environmental stress on a population only affects its size after several years. It has therefore been suggested that behavioural proxies such as foraging effort could be used to assess the short-term effects of environmental conditions on the wellbeing of a predator population. We demonstrate the potential of this approach in northern gannets Morus bassanus from the Sept-Iles Archipelago, France. This colony has been expanding rapidly for the past $60 \mathrm{yr}$, and is still growing faster than predicted from its size. However, using miniaturised GPS \& time-depth recorders attached to 21 breeding adults, we show that their foraging effort (assessed during the 2005 breeding season in terms of foraging trip duration and diving frequency) is higher than that of their British relatives. Further parameters such as foraging path length, path sinuosity, maximum foraging range, flight speed, flight time, dive depth, dive duration, and diet were also recorded. Using these field data and energetics modelling we predict that northern gannets breeding at the Sept-Iles will be highly sensitive to alterations of their foraging conditions. GPS-tracking indicates that birds from this colony forage exclusively within the western English Channel, with a strong preference for the tidal front between eastern and western Channel waters, northwest of Guernsey. This frontal zone attracts a wide range of marine organisms. It is also heavily fished, and a major oil spill hotspot. We conclude that the conservation of this marine area is critically important for northern gannets breeding at the Sept-Iles Archipelago.
\end{abstract}

KEY WORDS: GPS tracking - Interactions with fisheries - Marine protected areas - Marine top predators $\cdot$ Morus bassanus $\cdot$ Seabird oiling $\cdot$ Tidal front

Resale or republication not permitted without written consent of the publisher

\section{INTRODUCTION}

The status of an animal population can be assessed via diverse proxies. Population size and growth rate are generally used, but in long-lived species substantial and varying time lags can blur patterns and preclude straightforward analyses (Krebs 1996, Thompson \& Ollason 2001, Norrdahl \& Korpimaki 2002, Barbraud \& Weimerskirch 2003). Adult survival and the proportion of juvenile recruits, which condition population trends, are also powerful indexes of population status (Saether \& Bakke 2000, Anders \& Marshall 2005). These key variables nonetheless often require long-term studies and are challenging to record in wide-ranging species. In the shorter term, breeding parameters such as breeding phenology, breeding success, and the magnitude of the trade-off between parental investment and adult fitness can also 
be considered (Stearns 1989, Woller et al. 1992, Sanz 2002, Frederiksen et al. 2004). All such variables critically depend upon the capacity of parents to provide their offspring with food. The foraging effort of animal parents is therefore a potent short-term indicator of population health.

It has recently been suggested that in long-lived species such as seabirds, foraging parameters recorded during the breeding season could be used to better understand the status of populations, based on the premise that foraging performance influences reproductive success, and ultimately recruitment (Lewis et al. 2006). This approach is appealing from a management perspective, as studies of foraging behaviour can be performed within a much shorter timeframe than population studies, and results from the former can be quickly used as a base for management strategies. Conversely, population studies of long-lived, endangered species often only provide warning signals after the situation has degraded beyond the point of no return (Beissinger \& Westphal 1998).

After centuries of exploitation (Huxley 1884, Kurlansky 1998) there is growing evidence that humans significantly damage marine ecosystems (Jackson et al. 2001). This damage ranges across marine food webs, but its consequences become most apparent when they affect top predators (large predatory fishes, marine turtles, mammals and birds), which usually have high market value and are well known by the public. In the case of European seabirds, most populations have shown substantial growth during the 20th century, probably because they were recovering from past negative influences (Mitchell et al. 2004), but also because fisheries produced abundant discards available to some of the birds, and removed larger demersal fishes, thereby increasing the abundance of small pelagic fish. However, recent breeding failures in the North Sea and along the Atlantic coast suggest that bird populations are under considerable anthropogenic stress (Wanless et al. 2005a). Such stress can take the form of additional mortality caused by interactions with fishing gear and oil spills, disturbance and predation at the breeding sites, decreased fitness due to bioaccumulation of pollutants, and poorer feeding conditions linked both to climate change and overfishing (Tasker et al. 2000, Boersma et al. 2002, Burger \& Gochfeld 2002, Montevecchi 2002). The impact of these stresses is noticeable around the British Isles, which is the core breeding area for European seabirds (Mitchell et al. 2004), but they are even more marked in France (Cadiou et al. 2004). This is probably because the French coast is the southern edge of the breeding distribution for several species of European boreal seabirds. As a consequence, birds such as common guillemots Uria aalge, razorbills Alca torda, puffins Fratercula artica, kittiwakes Rissa tridactyla, and roseate terns Sterna dougallii are likely to disappear from the French mainland in the near future (Cadiou et al. 2004).

However, many other seabird species present in European waters do not seem to be threatened by human activities, rather they show an apparently healthy population growth (Mitchell et al. 2004). This is the case for northern gannets Morus bassanus, whose world population (75\% European) has increased by an average of $2 \% \mathrm{yr}^{-1}$ over the past $60 \mathrm{yr}$ (Wanless et al. 2005b). In theory such population growth should be less marked at the limit of the species' breeding range (Brown et al. 1996); nevertheless, the southernmost breeding colony, which is located in Brittany, France, grew by an average of $8 \%$ per year since 1939 (Siorat 2004). This colony was established during the 1930s on Rouzic, within the Sept-Iles nature reserve. It currently holds over 17000 pairs, and is the only breeding site of northern gannets in France. The Rouzic gannetry is the fine fleur of French biodiversity, with on-going media coverage and sustained public interest.

Population numbers of northern gannets have been monitored on Rouzic for over 50 yr (Siorat 2004). However, hardly anything is known about the foraging behaviour of breeding adults. Therefore, the actual ecological background, which allows exponential growth of the Rouzic colony, remains speculative.

We tested the hypothesis that highly profitable foraging conditions during the breeding season fuel the population growth of the French gannetry on Rouzic. Optimal foraging theory predicts that central place foragers such as breeding seabirds are significantly affected by intra-specific competition for food (Stephens \& Krebs 1986). In practice this means that, if resources are evenly distributed, individuals of larger colonies have to forage further away from the colony to feed themselves and their offspring and, as a consequence, larger colonies will grow slower than smaller ones. Such interplay of colony size, colony growth rate, and foraging effort has been demonstrated for ganneteries around the British Isles (Lewis et al. 2001). We used this theoretical and empirical framework to evaluate population growth and foraging parameters of northern gannets from Rouzic in an international context. Using this case study, we demonstrate that foraging parameters and energy balance provide powerful indexes of population health in the short term, and that studies of foraging strategies and foraging energetics in marine predators are an essential base for management policies. 


\section{MATERIALS AND METHODS}

Population parameters. Total numbers of gannet nests present on Rouzic during the breeding season were determined using direct counts and/or aerial photographs (for a detailed account of methods see Siorat \& Rocamora 1995). These numbers were recorded at irregular intervals between 1939 and 1955, but nearly every year between 1955 and 2005. Previous publications (Siorat \& Rocamora 1995, Siorat 1998, 2004) provided information about population trends between 1939 and 2000. This study is therefore an update of recent population developments (2000-2005).

As the total number of apparently occupied nests (AON, sensu Nelson 2002) rose exponentially between 1939 and 2005, AON numbers were log-transformed. The slope of the regression $\operatorname{Ln}(\mathrm{AON})$ versus Year was used as an estimate of the annual growth rate of the colony. Colony growth rate for the 1969 to 2004 period was compared with similar data for all UK gannetries presented in Wanless et al. (2005b). As in this publication, we plotted the rate of increase between 1969 and 2004 versus colony size in 1969 on a log-log scale.

The reproductive success of between 14 and 82 nests was monitored yearly between 1991 and 1997, and in 2002. It was expressed as the percentage of nests from which a chick fledged after an egg had been observed at the beginning of the breeding season (fledged from laid, sensu Nelson 2002).

Data logger deployments. Field studies were conducted on Rouzic $\left(48^{\circ} 54^{\prime} \mathrm{N}, 3^{\circ} 26^{\prime} 11^{\prime \prime} \mathrm{W}\right)$ between June 27 and July 72005 under permits of the board of the Réserve Naturelle des Sept Iles. Adult birds raising a total of 21 chicks were caught at the nest site using a noose mounted onto a telescopic pole and fitted with a single data logger (see specifications below). The devices were attached to the lower back with white Tesa ${ }^{\circledR}$ tape to match the colour of the plumage. This technique ensures that the devices stay on the bird during their voyage at sea, and that tape and data logger can be subsequently removed with minimal damage to the plumage (Wilson et al. 1997). We took great care to minimize the impact of our study on the birds. Adults were mainly caught at dawn to avoid heat stress (Hochscheid et al. 2002). We caught birds when both parents were present at the nest site. The bird that was about to initiate a foraging trip was equipped with a data logger, and the second remained at the nest site to guard the chick. Handling lasted less than 10 min in all cases, and we covered the bird's head to reduce stress. Birds were only equipped for a single foraging trip lasting a maximum of $29 \mathrm{~h}$.

These field techniques have been used on several occasions for cape gannets Morus capensis and in African penguins Spheniscus demersus (Grémillet et al. 2004, Ryan et al. 2004, Lewis et al. 2006, Pedersen et al. 2006) with no measurable impact on the behaviour and the wellbeing of the animals. We nonetheless compared foraging trip durations of birds equipped with data loggers with those of non-equipped control birds. The latter were colour-marked (with bio-compatible dye) without being handled using a paintbrush mounted onto a telescopic pole. Foraging trip durations were subsequently determined via hourly visual checks performed between dawn and dusk (gannets do not enter or leave the colony during the night). We assumed that in the event of a disturbance caused by the loggers the foraging trip duration of gannets would be modified (see Taylor et al. 2001).

Northern gannets are monomorphic, but nape biting is more or less exclusively performed by males (Redman et al. 2002). Nevertheless, we could not sex all birds reliably during this study, and we therefore did not explore inter-sexual differences. As birds were chosen at random, we nonetheless assume that our sample contains an approximately equal number of males and females. Finally, the study nests were selected at random, i.e. not only from the periphery of the colony, but also from $10 \mathrm{~m}$ within it (i.e. the length of the catching pole) so as to avoid biases due to potential regional age effects (Nelson 2002).

Data logger specifications and analysis of electronic data sets. We used 2 types of data loggers: (1) a 1-channel GPS data logger (NewBehaviour, $95 \times 48 \times$ $24 \mathrm{~mm} ; 65 \mathrm{~g}$, i.e. $2.1 \%$ of the body mass of the birds, see Grémillet et al. 2004 for details) set to record latitude, longitude and speed every $10 \mathrm{~s}$; and (2) a GPS data logger combined with a time-depth recorder (GPSlog; Earth and Ocean Technologies, $96 \times 39 \times$ $26.5 \mathrm{~mm} ; 75 \mathrm{~g}$, i.e. $2.4 \%$ of the body mass of the birds, see Ryan et al. 2004 for details) which was programmed to record longitude, latitude and speed every 2 min when the bird was not diving, and every second for $4 \mathrm{~min}$ after each dive exceeding $3 \mathrm{~m}$. Depth was recorded every second with a resolution of $0.10 \mathrm{~m}$ throughout the deployment period.

Dive profiles were analysed using MultiTrace for Windows (Jensen Software Systems) with $0.5 \mathrm{~m}$ as the dive threshold. We determined the total number of dives, average dive duration and average maximum depth of dives for each foraging trip.

GPS positions and speed values recorded outside of the breeding colony were analysed in 3 different ways: (1) We calculated foraging trip duration, foraging path length, average speed (when the bird was flying, i.e. $>10 \mathrm{~km} \mathrm{~h}^{-1}$ ), maximum distance to the colony, and time spent flying or resting at the water surface (for definitions see Grémillet et al. 2004). (2) We selected positions for birds that were flying, but displayed a very sinuous path. Such positions are associated to active 
feeding behaviour (in contrast to more rectilinear travelling flights, see Grémillet et al. 2004 for details on filtering technique). Kernel analysis (Wood et al. 2000) allowed us to generate topographic maps of the density of positional fixes per unit-area. In order to verify the validity of the algorithm used to filter the feeding positions, we compared the occurrence of such feeding locations with that of dives, which had been recorded synoptically for the 6 birds equipped with a GPSlog. (3) Finally, all GPS tracks were analysed after Weavers (1992) to estimate the relative amount of time spent by the birds per $0.1 \times 0.1^{\circ}$ grid cell (approximately $7.1 \times$ $11.1 \mathrm{~km}$ ). This index of area utilisation was also represented as a topographic map.

The spatial data presented here bear a certain level of pseudoreplication. In order to minimize this problem we only monitored 1 foraging trip per bird, we filtered the GPS positions that were associated with feeding activities, therefore discarding commuting sections, and we used Kernel analyses after Wood et al. (2000). As can be gathered from the result section, we present our spatial data in 3 different ways (see Figs. 3-5) in order to assess the validity of our findings.

Energetics modelling. We estimated the daily energy requirements $\left(\mathrm{kJ} \mathrm{d}^{-1}\right)$, daily food intake $\left(\mathrm{g} \mathrm{d}^{-1}\right)$, and metabolic scope (average metabolic rate expressed as a multiple of BMR) of adult northern gannets breeding on Rouzic after Enstipp et al. (2006). This algorithm uses time budget information gained using data loggers and published values of metabolic rates for the different activities. The model also takes into account the energy required to feed the chick. Input values such as foraging trip duration, time spent flying, body mass and chick age were extracted from our field data. Others were used as specified by Enstipp et al. (2006).

Further parameters. Gannets caught or disturbed at the nest often regurgitated food. Such prey-items were collected opportunistically. Most of them were sufficiently fresh to be identified on site, following Muus \& Dahlstrøm (1985). This allowed us to define the diet of breeding birds during the study period.

In breeding gannets one parent usually stays at the nest to guard the 1-chick brood, unless feeding conditions deteriorate, forcing both parents to forage simultaneously. Total time spent by both parents together at the nest is consequently a good index of their workload (Lewis et al. 2004). We therefore recorded the proportion of chicks left unattended during the study period, and the duration of change over periods (time period between the return of one parent and the departure of its mate), which were observed at random between dawn and dusk.

All birds caught were weighed to the nearest $25 \mathrm{~g}$ using a spring balance (Salter Brecknell Super Sam- son, RACO Industries). Chicks were aged in weekly categories using plumage characteristics after Nelson (2002).

\section{RESULTS}

\section{Population parameters and nest attendance patterns}

The total number of gannet nests counted on Rouzic increased steadily between 1939 (30 AON) and 2005 (17 507 AON). In accordance with Siorat \& Rocamora (1995), we identified 3 main growth phases between 1939 and 1995 (Fig. 1): until 1965 colony growth was rapid, with an average annual growth rate of $25.6 \%$. Between 1967 and 1979, this average rate levelled off at $5.5 \% \mathrm{yr}^{-1}$. From 1981 until 1994, annual colony growth increased again, with an average $8.5 \%$. Finally, data collected since the study by Siorat \& Rocamora (1995) showed a decrease in annual growth rates, with an average of $4.0 \%$ for the 1995 to 2005 period. Comparison of the Rouzic colony growth rate with growth rates of UK gannetries for the 1969 to 2004 time period showed that Rouzic grew more rapidly than UK colonies of similar size (Fig. 2). Breeding success (the proportion of breeding couples which fledged a chick), assessed annually between 1991 and 1997 and in 2002, varied between $85.7 \%$ in 1991 and $96.9 \%$ in 1996 , with an average of $89.5 \%$.

During the study period in late June to early July 2005 most chicks were between 4 and 6 wk old (max. observed 9 wk). We did not observe a single

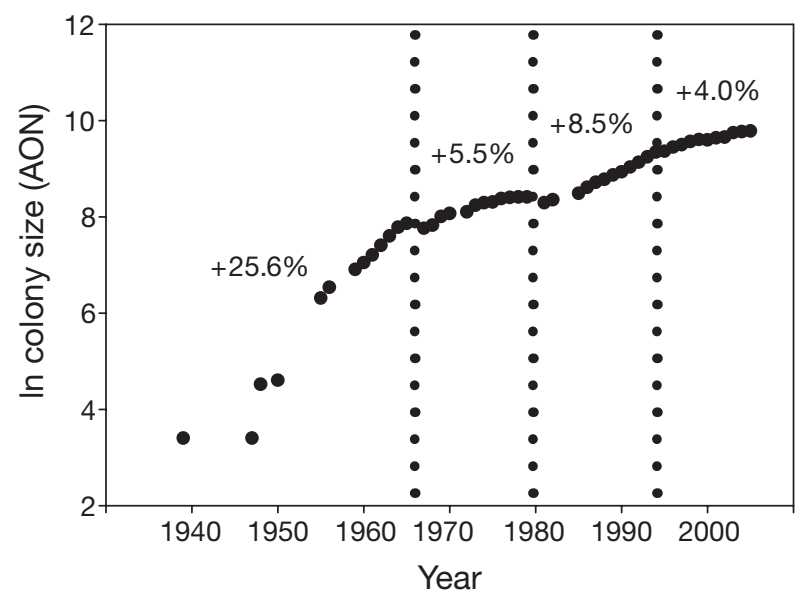

Fig. 1. Morus bassanus. Size of the northern gannet colony on Rouzic, Sept-Iles Archipelago, France, increased steadily throughout the second half of the 20th century. Colony size is given as $\ln$ of apparently occupied nests (AON). We also provide average annual growth rates (\%) for different time periods. Note that, even if the colony growth rate is reduced in recent years, it is still twice as high as for gannet colonies around the British Isles $(2 \%$ on average; see Wanless et al. 2005b) 


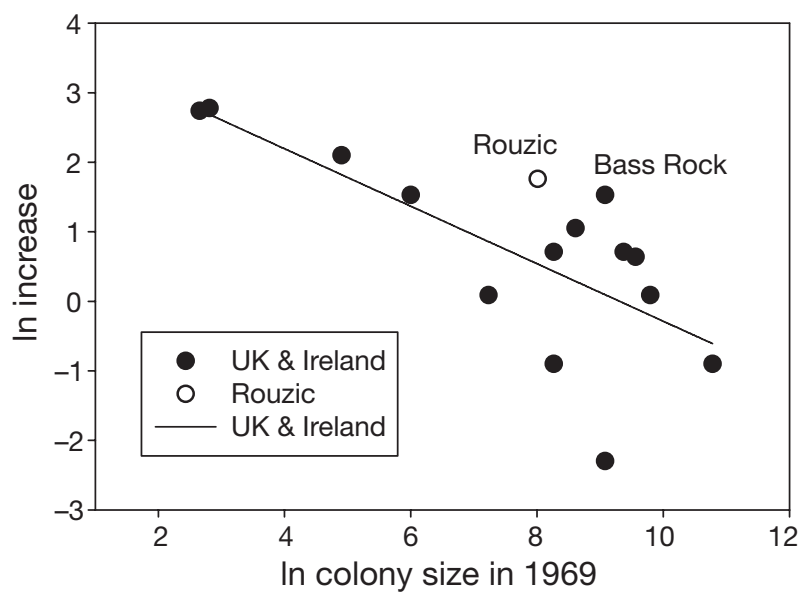

Fig. 2. Morus bassanus. The French northern gannet colony on Rouzic (O) has increased faster than UK colonies of similar size (๑, data from Wanless et al. 2005b, Fig. 3). Note that this is also true for the Bass Rock colony, which is 2.7 times larger than Rouzic (48065 vs. 17700 apparently occupied nests, AON)

chick left unattended at the nest site, i.e. no parents seemed to forage simultaneously. Adults spent $6.3 \mathrm{~min}$ (median, $\mathrm{n}=20$ ) together at the nest site during switch over.

\section{Foraging behaviour}

All data loggers were recovered after a single foraging trip, and all birds continued to breed normally after the logger deployment. Average foraging trip duration was similar in equipped and control birds $(17.8 \pm 8.6 \mathrm{~h}$, $\mathrm{n}=20$ and $17.3 \pm 6.3 \mathrm{~h}, \mathrm{n}=13$, respectively, $t=0.17, \mathrm{p}=$ 0.86). We compared foraging trip duration and colony size for Rouzic gannets and gannets from UK colonies using data presented in Lewis et al. (2001) (Fig. 3). This revealed that Rouzic gannets performed significantly longer foraging trips than UK gannets attending colonies of similar size $\left(R_{10}=0.84, \mathrm{p}<0.05\right.$; Dixon's outlier test, Sokal \& Rohlf 1981).

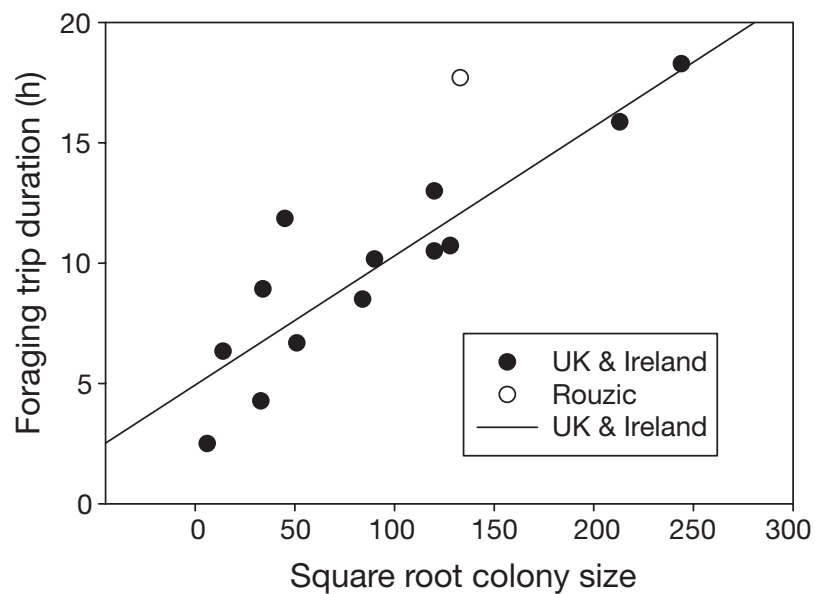

Fig. 3. Morus bassanus. Gannets from Rouzic work harder than gannets from colonies of similar size situated around the British Isles. Data from the British Isles are taken from Lewis et al. (2001, their Fig. 3)

One GPSlog did not record GPS positions, and we therefore gathered a total of 20 complete GPS tracks and 7 dive depth traces. Summary statistics of foraging trip characteristics are given in Table 1. Birds spent $50 \%$ of their foraging time flying, and $50 \%$ at the water surface. Although their average flight speed was only around $49 \mathrm{~km} \mathrm{~h}^{-1}$, they regularly reached horizontal speeds of over $100 \mathrm{~km} \mathrm{~h}^{-1}$ (max. $129 \mathrm{~km} \mathrm{~h}^{-1}$ ). The deepest recorded dive had a maximum depth of $12 \mathrm{~m}$ and lasted $26 \mathrm{~s}$, but most dives were much shallower, with principal modes around 2 and $6 \mathrm{~m}$ (Fig. 4).

We found significant positive relationships between foraging trip duration and maximum foraging range $\left(F_{1,19}=17.63, \mathrm{p}=0.001\right)$, and between foraging trip duration and foraging path length $\left(F_{1,13}=31.06, \mathrm{p}<\right.$ 0.001):

$$
\begin{gathered}
\text { Maximum foraging range }(\mathrm{km})= \\
2.88 \times \text { foraging trip duration }(\mathrm{h})+49.2 \\
\text { Foraging path length }(\mathrm{km})= \\
21.06 \times \text { foraging trip duration }(\mathrm{h})+66.0
\end{gathered}
$$

Table 1. Morus bassanus. Adult body mass, chick age, and foraging characteristics of northern gannets from Rouzic, Sept-Iles, studied during the chick-rearing phase. Birds $(\mathrm{N}=21)$ are taken as the sampling unit, but information derived from GPS tracks is summarized for 20 birds, while diving information is summarized for 7 birds

\begin{tabular}{|lcccccccrrr}
\hline & $\begin{array}{c}\text { Body } \\
\text { mass } \\
(\mathrm{g})\end{array}$ & $\begin{array}{c}\text { Chick } \\
\text { age } \\
(\mathrm{wk})\end{array}$ & $\begin{array}{c}\text { Foraging } \\
\text { trip } \\
\text { duration }(\mathrm{h})\end{array}$ & $\begin{array}{c}\text { Foraging } \\
\text { path } \\
\text { length }(\mathrm{km})\end{array}$ & $\begin{array}{c}\text { Speed } \\
\text { at sea } \\
\left(\mathrm{km} \mathrm{h}^{-1}\right)\end{array}$ & $\begin{array}{c}\text { Max. } \\
\text { distance to } \\
\text { colony }(\mathrm{km})\end{array}$ & $\begin{array}{c}\text { Sinuosity } \\
\text { of foraging } \\
\text { path }\end{array}$ & $\begin{array}{c}\text { Flight } \\
\text { time } \\
(\mathrm{h})\end{array}$ & $\begin{array}{c}\text { Dives } \\
\text { per } \\
\text { trip }\end{array}$ & $\begin{array}{c}\text { Dive } \\
\text { duration } \\
(\mathrm{s})\end{array}$ \\
\hline Mean & 3101 & 4.7 & 17.7 & 479 & 48.8 & 100 & 1.12 & 8.9 & 41 & 6 \\
SD & 197 & 1.5 & 8.5 & 206 & 3.6 & 35 & 0.07 & 4.0 & 13 & 2 \\
Min & 2650 & 2.0 & 4.5 & 140 & 42.9 & 40 & 1.02 & 2.1 & 25 \\
Max & 3375 & 7.0 & 28.9 & 856 & 54.7 & 176 & 1.22 & 17.6 & 56 \\
\hline
\end{tabular}




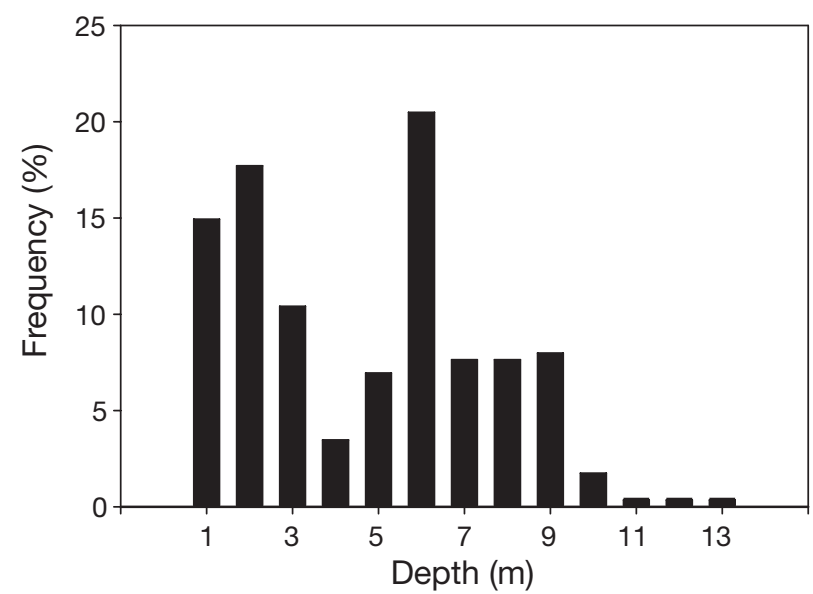

Fig. 4. Morus bassanus. Frequency distribution (\% of all observations, $\mathrm{n}=288$ dives) of the maximum depth attained by 7 breeding northern gannets from Rouzic, Sept-Iles archipelago, during foraging trips in the western English Channel

Figs. 5-7 show the spatial data gathered via GPS tracking. Both raw tracks (Fig. 5) and more refined graphs (Figs. 6-7) lead to the same conclusions about the space utilization by Rouzic gannets: during the study period birds forage exclusively within the western English Channel (hereafter WEC) between the Bay of Mont St Michel and Cornwall. They made extensive use of the central WEC northwest of Guernsey and visited the zone of the Minquiers between Chausey and Jersey. They also exploited more coastal areas as the Bays of St Brieux and Dinard. A significant number of position fixes were recorded in vicinity of the breeding colony. They are probably due to birds resting and washing before or after their foraging trip, but local feeding cannot be excluded (F. Siorat pers. obs.).

Parallel analysis of GPS tracks and dive depth traces for the 6 birds successfully monitored with GPSlog data loggers revealed that each recorded dive corresponds with a highly sinuous section of the GPS tracks which we identified as a feeding location (sensu Grémillet et al. 2004). Conversely, each section of the GPS tracks characterised as highly sinuous by our filter was not far from a dive. In $75 \%$ of all cases there were $<5 \mathrm{~min}$ between the occurrence of a dive and a sinuous section $(3.1 \pm 4.5 \mathrm{~min}$ on average). These results confirm the validity of the method used to identify GPS positions associated with feeding activity. We do not know whether birds foraged successfully at these locations, but we can nonetheless consider that highly sinuous sections of their foraging paths were associated with active prey searching via plunge-diving. However, our assessment of foraging locations of northern gannets breeding on Rouzic remains conservative, as gannets can also catch prey at the water surface. Such behaviour is not visible on dive traces, and we are unsure whether it is linked to a highly sinuous foraging track prior to landing on the water surface.

We gathered 10 regurgitations containing 24 prey items; 6 regurgitations could be weighed entirely (average mass $140 \pm 50 \mathrm{~g}$ ). Birds mainly fed on garfish Belone belone (38\%), but also took mackerel Scomber scombrus (17\%), pollack Pollachius pollachius (13\%), sandeel Ammodytes sp. (16\%), and gurnard Aspitrigla cuculus $(16 \%)$. These percentages refer to the numbers of individual fish and therefore overestimate the proportion of sand eels consumed, as these are far smaller than all other prey items. Visual inspection of prey items suggested that they had been caught alive by the birds, although demersal fish such as gurnards could have been fishery discards. This limited sample suggests that the diet of gannets at Rouzic is markedly different from that of North Sea gannets, which includes a large proportion of mackerel, and resembles that of gannets from the Irish Sea, which forage on a more varied diet (Lewis et al. 2003).

\section{Energy requirements}

Using the bioenergetics model defined by Enstipp et al. (2006) we estimated that adult northern gannets during chick rearing on Rouzic require an average of

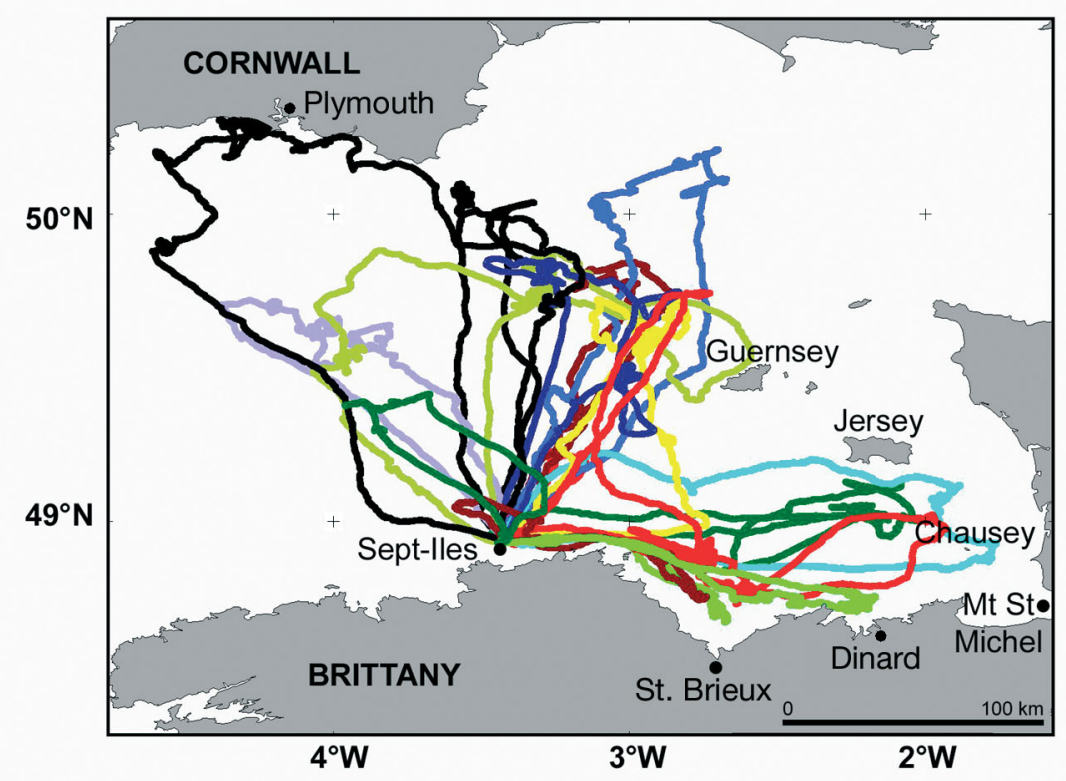

Fig. 5. Morus bassanus. GPS tracks recorded during the foraging trips of 20 northern gannets from the Sept-Iles in the western English Channel. Different colours show tracks from different birds 


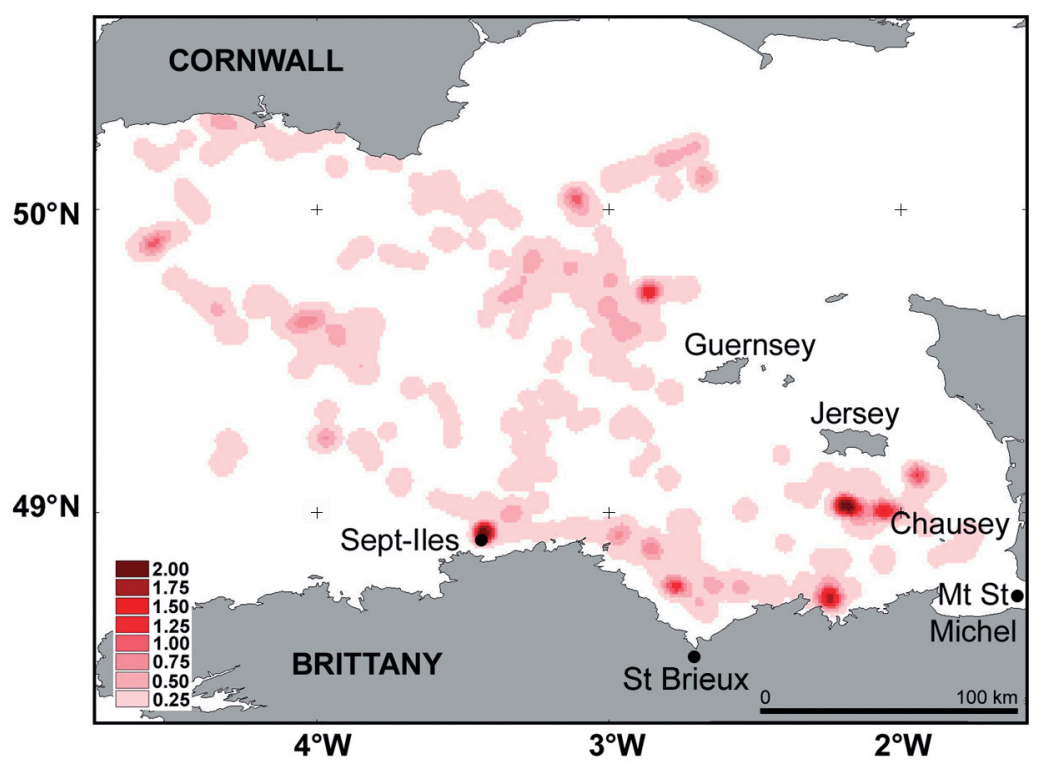

Fig. 6. Morus bassanus. Topographic representation of the density of GPS positions associated to active foraging during trips performed by 20 northern gannets from the Sept-Iles in the western English Channel (see 'Materials and methods' for details of filtering procedure). The colour code gives the density of positions per $0.01 \times 0.01^{\circ}$

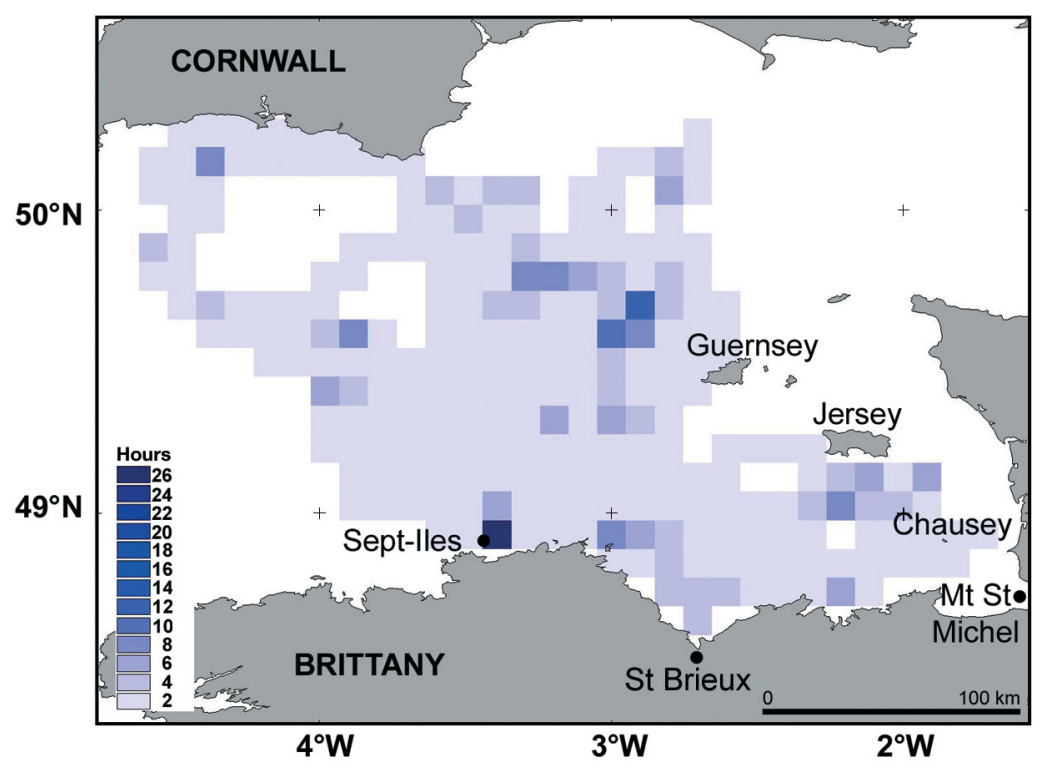

Fig. 7. Morus bassanus. Topographic representation of the time (h) spent per unit-area $\left(0.1 \times 0.1^{\circ}\right.$ grid cells $)$ by 20 northern gannets from the Sept-Iles during foraging trips in the western English Channel. Note that birds foraged extensively within the central part of the English Channel, probably along the tidal front between Atlantic and Channel surface waters. They nonetheless also seek coastal areas on both sides of the Channel

$5210 \mathrm{~kJ} \mathrm{~d}^{-1}$ for themselves, and an additional $1590 \mathrm{~kJ}$ $\mathrm{d}^{-1}$ for their chick (i.e. $795 \mathrm{~kJ} \mathrm{~d}^{-1}$ parent $^{-1}$ ). This converts to an average daily food intake of $1200 \mathrm{~g}$ of fish for the parent alone and $1380 \mathrm{~g}$ of fish for 1 parent and its chick. Overall, the average adult metabolic rate is $4.15 \times$ BMR.

\section{DISCUSSSION}

\section{Mismatch between population dynamics and foraging effort}

Unlike several populations of marine birds in European waters, particularly in France, the colony of northern gannets on Rouzic, Sept-Iles Archipelago, has shown substantial growth rates ever since its foundation in the 1930s. Its average yearly growth was 4 times that of gannetries around the British Isles during the same period $(8 \%$ and $2 \%$, respectively; Wanless et al. 2005). The size-specific growth rate of the Rouzic colony for the 1969 to 2004 period was also markedly higher than that for UK colonies of similar size (Fig. 2). Using population models Siorat \& Rocamora (1995) showed that such high annual growth rates are probably not only due to recruitment of juveniles born on Rouzic, but also to the immigration of young breeders from other colonies. This indicates that the SeptIles are an extremely valuable breeding site for northern gannets; this is confirmed by the very high breeding success that we recorded on Rouzic during the 1990s, and in 2002. Such average breeding success (proportion of chicks fledged from laid eggs) of $89.5 \%$ is $>10 \%$ higher than the UK average (Nelson 2002).

Consequently, if we were to consider population growth and breeding parameters as sole indexes of the status of French northern gannets, we would conclude that the southernmost current breeding site for this species shows very healthy growth, and that no specific protection measures need to be taken to ensure its perpetuation.

However, detailed examination of foraging patterns and energy balance provides a different picture. (1) Foraging trip durations, which are a good index of overall foraging effort, are proportionally longer for birds from Rouzic than for gannets breeding at colonies of similar size around the British Isles (Fig. 3). (2) Breton gannets perform $4.0 \pm$ 1.0 dives $\mathrm{h}^{-1}$ on average when they are at sea, whereas birds from the Bass Rock colony only dive $1.4 \pm 0.4$ times $\mathrm{h}^{-1}$ (Lewis et al. 2002; $t=8.6, \mathrm{p}<0.001$ ). The lat- 
ter colony is much larger and gannets attending it should, in theory, be more affected by intra-specific competition. This particular point should nonetheless be considered with caution since both studies used different devices with different sampling intervals. (3) Rouzic gannets travel extensive distances when they are at sea, with an average foraging path length of $480 \mathrm{~km}$ (maximum $856 \mathrm{~km}$ ). Unfortunately, this path length cannot be directly compared with data from former studies, as these were based upon satellite tracking, which only provides an average of 6 positions $\mathrm{d}^{-1}$ (Hamer et al. 2001), whereas GPS tracking allows the recording of at least 1 position every few minutes. However, comparison of our data with satellite tracks (Hamer et al. 2001), and with preliminary GPS tracking of northern gannets from the North Sea (Hennicke et al. unpubl. data) shows that birds from the Bass Rock colony perform far more rectilinear, directional trips (i.e. birds tend to fly from the colony straight towards a distant foraging locations, exploit this food patch, and then fly more or less directly back to their breeding site). In contrast, birds from Rouzic only foraged within the WEC, with moderate maximum foraging ranges (100 km on average; Table 1), yet they displayed extremely tortuous foraging paths (Fig. 5). As a result, the linear relationship between maximum foraging range and foraging trip duration has a much steeper slope in northern gannets from 2 British colonies (Hamer et al. 2001), than for birds from Rouzic (slopes of ca. 7 versus ca. 3, see Eq. 1). Note that this comparison is appropriate even if Hamer et al. (2001) used satellite telemetry, since maximum foraging range and foraging trip duration are far less affected by varying sampling intervals than foraging path length.

Analysis of foraging modes indicate that northern gannets from Rouzic work hard to get their food, and this assertion is confirmed by analysis of their energy budget. Output from the model proposed by Enstipp et al. (2006) reveal that adults breeding on Rouzic require $1380 \mathrm{~g}$ fish $\mathrm{d}^{-1}$ to sustain themselves and to feed their chick. This is $7 \%$ more than for birds breeding on Bass Rock (Enstipp et al. 2006), a colony that is 2.7 times larger than Rouzic (48065 versus 17700 AON). On Bass Rock birds should be exposed to much higher levels of intra-specific competition for food, and should therefore need more energy to exploit scarcer/more distant food patches than on Rouzic. Also, energetics modelling reveals that the average field metabolic rate of adult northern gannets from Rouzic is $>4 \times$ BMR (i.e. 4.15), which has been suggested to represent the maximum work-load for a bird during the reproduction phase (Drent \& Daan 1980). In comparison, the field metabolic rate of adult northern gannets from the much larger Bass Rock colony averages $3.9 \times \mathrm{BMR}$ (Enstipp et al. 2006).
We therefore conclude that, despite apparently healthy population developments, birds raising small chicks on Rouzic during the 2005 breeding season faced a work-load which was far above the average foraging effort expected for northern gannets attending a colony of this size. It can be speculated whether these limitations are actually linked to the strong dynamics of the colony i.e. the predator-prey system within which French northern gannets evolve has now reached its carrying capacity, and is being limited by density-dependent effects. Reduced colony growth rates recorded in recent years might be a sign of this process (Fig. 1), although reduced immigration has also to be considered.

Whatever the reasons for this population trend, fact is that northern gannets breeding at this colony in 2005 had a relatively tight time and energy budget, with little buffer to compensate for variable environmental conditions. Another sign of this situation is that parents did not leave their chicks unattended, yet they spent relatively short time periods together at the nest between foraging trips (ca. 6 min). Similarly short change-over durations have been recorded in foodlimited cape gannets (Lewis et al. 2006).

\section{Conservation implications}

Our results suggest that northern gannets from Rouzic feed within the WEC during the chick-rearing phase and that this relatively confined water body limits their foraging range (see Pedersen et al. 2006). Combined information about their distribution at sea (Figs. 5-7), their dive patterns (Fig. 4) and their diet allow us to better define their ecological niche within this zone: as in other areas of the North Atlantic, Rouzic gannets predominantly exploit pelagic shoaling fish caught by brief plungediving within the first few meters of the water column. Within the WEC, they employed 2 contrasting strategies during the study period: (1) Exploitation of prey resources within the central WEC, northwest of Guernsey (Figs. 5-7). This foraging hot spot corresponds to the deepest part of the Channel and, crucially, to a high productivity area located within a tidal front. This tidal front features a boundary layer, oscillating between stratified Atlantic surface waters in the west and highly mixed surface Channel waters in the east (Southward et al. 2005). Such a high-productivity zone attracts marine top predators (Sims et al. 2005), and we confirm its appeal to northern gannets (see also Pingree et al. 1974, Siorat 1992, White \& Reid 1998). (2) Gannets from Rouzic also visit more coastal areas on both sides of the Channel, from the Bay of Mont St Michel to the vicinity of Plymouth.

Our results have important conservation implications: (1) Northern gannets breeding on Rouzic mainly 
foraged within the central English Channel during the chick-rearing phase of the 2005 breeding season. This zone is one of the busiest shipping routes in the world, and a major oil spill hotspot (Veites et al. 2004). Although gannets are generally less sensitive to oil spills than other seabirds, such as alcids, pollution events occurring within this zone could severely impact the French gannet population. Such pollution is not restricted to oil and other chemicals; the discard of litter, in particular of disused fishing nets, is also a serious threat to gannets (Montevecchi 1991). (2) Chickrearing gannets from Rouzic seem to gather their food from relatively confined zones of the WEC. The chickrearing phase is the most demanding period of the year for northern gannets, as they then face the increased food requirements of their chicks, the constraints of central place foraging, and substantial levels of intraspecific competition (Nelson 2002). As we have shown, adult birds work hard during this period. They might therefore be extremely sensitive to changes in their feeding conditions within the WEC.

We often perceive the English Channel primarily as a busy shipping route, but it is also a heavily fished area. Over 4000 fishing units operate in the Channel (41\% from France, $59 \%$ from the UK) and catch a total of $230000 \mathrm{t}$ annually. This corresponds to approximately $0.25 \%$ of the world's fisheries over only $0.021 \%$ of the total maritime surface (Ulrich et al. 2002, Guitton et al. 2003, FAO 2005, available at: www.fao.org/fi/ statist/statist.asp). Two thirds of this catch occurs in the WEC, and it includes ca. 26600 t (>10\% of all landings) of mackerel (Guitton et al. 2003). The mackerel stock in the English Channel is presently fully exploited (Guitton et al. 2003). This might be why this species, which is usually a major prey item for northern gannets in European waters (Nelson 2002) represented only $17 \%$ of the diet of gannets from Rouzic during our study period. French gannets seem to switch to other species which are only moderately exploited by human fisheries, such as haddock and gurnard (Guitton et al. 2003), or to species with no official market value (sandeels and garfish). In particular garfish appears to be an important prey item for gannets from Rouzic.

With regard to the management of the marine ecosystem in the WEC, we therefore suggest that top predators such as northern gannets might be critically sensitive to further declines in mackerel stocks, and to any significant declines in the stocks of their other prey, in particular garfish. Changes in prey distribution and abundance which impact seabird behaviour are not only caused by fisheries. They might also be due to climate change (Frederiksen et al. 2004) and regime shifts (Beaugrand 2004). The coast of France is the southern boundary of many seabird populations, including northern gannets. Such boundaries are pre- dicted to be strongly affected by climate change and ecosystem shifts (Brown et al. 1996).

Gannets do not exclusively feed on live prey, as they can also gather fishery discards (Garthe et al. 1996). Although most prey items examined during our study seemed to have been caught alive, we cannot exclude that some of them were discards. This might be the case for gurnards, which are primarily bottom dwelling fish, and cannot be easily targeted by gannets in a natural situation. Therefore, we cannot exclude that intense fishery activities in the English Channel might compensate for some competition by providing alternative food sources to the birds.

\section{Conclusions}

Based on our field data we reject the hypothesis that substantial population growth of the Rouzic colony is based upon highly profitable foraging conditions enabling moderate foraging investment by adult gannets, at least during our study period. Conversely, our study indicates that French northern gannets have a higher work load than predicted for a colony of the size of Rouzic, and keep a very tight time budget and energy balance. We therefore predict that even minor changes in the profitability of their foraging grounds might have drastic short-term effects on their breeding success and their survival, with knock-on effects on population numbers in the longer term.

Our study confirms that wildlife management cannot be solely based upon the monitoring of population trends (Primack 2000). Northern gannets tend to breed within few, very large colonies. Such breeding sites have to be secured and freed from invasive alien species. This is the case for the Rouzic breeding site, which has been a part of the Sept-Iles nature reserve since 1912 , i.e. long before the establishment of the gannet colony. However, even more importantly, the foraging grounds of the birds must also be adequately managed. In this context our study confirms the great importance of the tidal front zone between the western and eastern English Channel for marine wildlife, and stresses the need for special conservation measures within this zone. Such a management plan should not follow a classic single-species management strategy, but should rather consider the WEC ecosystem as an entity (ecosystem-based management, see Cury et al. 2005).

Our study has been conducted over a short time frame, and we have no information about the foraging ecology of French northern gannets during the rest of the yearly cycle. Our rationale was that gannets attain their maximum work load during the chick-rearing phase and that this was the time period during which constraints on their foraging performance were most 
likely to become apparent. However, further investigations are required to assess potential variability in the foraging patterns of northern gannets from Rouzic, which might modify our conclusions. Such variability might arise at the individual level (during repeated foraging trips) and at the annual level (see Lewis et al. 2005). Foraging strategies and food requirements also have to be defined during other phases of the breeding season, and outside of the breeding season. These combined investigations will enable management plans to identify marine biodiversity hotspots such as the English Channel tidal front, which deserve special protection.

Acknowledgements. This study was funded by the Centre National de la Recherche Scientifique via an ACI grant to D.G. and by the DEPE-IPHC-CNRS, Strasbourg. L.P. was funded by a studentship of the French Ministry of Research. We benefited from substantial logistics support from the Station Ornithologique de l'Ile Grande, Ligue pour la Protection des Oiseaux. We are grateful to the staff at the Station Ornithologique de l'Ile Grande for their help and tolerance, particularly to Armel Deniau for ensuring transportation to and from Rouzic under challenging weather conditions. D.G. warmly thanks the seabird team at CEH-NERC, in particular Sarah Wanless, Mike P. Harris, Morten Frederiksen, Sue Lewis and Francis Daunt for very fruitful discussions during a sabbatical at CEH's Banchory Research station. Thanks also to Morten Frederiksen who efficiently assisted D.G. in matters linked to population dynamics, to Clara Ulrich-Rescan, Jérôme Guitton, Alan J. Southward, and David W. Sims for some crucial input about human fisheries and physical oceanography in the English Channel, to Manfred Enstipp for calculating the theoretical energy requirements of Rouzic gannets and checking the English, and to 3 anonymous referees for pertinent input.

\section{LITERATURE CITED}

Anders AD, Marshall MR (2005) Increasing the accuracy of productivity and survival estimates in assessing landbird population status. Conserv Biol 19:66-74

Beaugrand G (2004) The North Sea regime shift: evidence, causes, mechanisms and consequences. Prog Oceanogr 60:245-262

Barbraud C, Weimerskirch H (2003) Climate and density shape population dynamics of a marine top predator. Proc R Soc Biol Sci Ser B 270(1529):2111-2116

Beissinger SR, Westphal MI (1998) On the use of demographic models of population viability in endangered species management. J Wildl Manag 62:821-841

Boersma PD, Clark JA, Hillgarth N (2002) Seabird conservation. In: Schreiber EA, Burger J (eds) Biology of Marine Birds. CRC Press, Boca Raton, FL, p 559-579

Brown JH, Stevens GC, Kaufman DM (1996) The geographic range: size, shape, boundaries, and internal structure. Annu Rev Ecol Syst 27:597-623

Burger J, Gochfeld M (2002) Effects of chemicals and pollution on seabirds. In: Schreiber EA, Burger J (eds) Biology of marine birds. CRC Press, Boca Raton, FL, p 485-525

Cadiou B, Pons JM, Yésou P (2004) Oiseaux marins nicheurs de France métropolitaine (1960-2000). Editions Biotope, Mèze
Cury PM, Mullon C, Garcia SM, Shannon LJ (2005) Viability theory for an ecosystem approach to fisheries. ICES J Mar Sci 62:577-584

Drent RH and Daan S (1980) The prudent parent: energetic adjustments in avian breeding. Ardea 68:225-252

Enstipp MR, Daunt F, Wanless S, Humphreys EM, Hamer KC, Benvenuti S, Grémillet D (2006). Foraging energetics of North Sea birds confronted with fluctuating prey availability. In: Boyd IL, Wanless S, Camphuysen CJ (eds) Top predators in marine ecosystems. Symp Zool Soc London. Cambridge University Press, Cambridge

Frederiksen M, Harris MP, Daunt F, Rothery P, Wanless S (2004) Scale-dependent climate signals drive breeding phenology of three seabird species. Global Change Biol 10:1214-1221

Garthe S, Camphuysen CJ, Furness RW (1996) Amounts of discards by commercial fisheries and their significance as food for seabirds in the North Sea. Mar Ecol Prog Ser 136: $1-11$

Grémillet D, Dell'Omo G, Ryan PG, Peters G, Ropert-Coudert Y, Weeks S (2004) Offshore diplomacy, or how seabirds mitigate intra-specific competition: a case study based on GPS tracking of cape gannets from neighbouring breeding sites. Mar Ecol Prog Ser 268:265-279

Guitton J, Dintheer C, Dunn MR, Morizur Y, Tétard A (2003) Atlas des pêcheries de la Manche. Editions Ifremer

Hamer KC, Phillips RA, Hill JK, Wanless S, Wood AG (2001) Contrasting foraging strategies of gannets Morus bassanus at two North Atlantic colonies: foraging trip duration and foraging area fidelity. Mar Ecol Prog Ser 224: 283-290

Hochscheid S, Grémillet D, Wanless S, du Plessis MA (2002) Black and white under the South African sun: are juvenile Cape gannets heat stressed? J Therm Biol 27:325-332

Huxley TH (1884) Inaugural address. Fish Exhibit Lit 4:1-22

Jackson JBC, Kirby MX, Berger WH, Bjorndal KA and 15 others (2001) Historical overfishing and the recent collapse of coastal ecosystems. Science 293:629-637

Krebs CJ (1996) Population cycles revisited. J Mammal 77: 8-24

Kurlansky M (1998) Cod: a biography of the fish that changed the world. Penguin Books

Lewis S, Sherratt TN, Hamer KC, Wanless S (2001) Evidence for intra-specific competition for food in a pelagic seabird. Nature 412:816-819

Lewis S, Sherratt TN, Hamer KC, Harris MP, Wanless S (2003) Contrasting diet quality of northern gannets Morus bassanus at two colonies. Ardea 91:167-176

Lewis S, Hamer KC, Money L, Griffiths R, Wanless S, Sherratt TN (2004) Brood neglect and contingent foraging behavior in a pelagic seabird. Behav Ecol Sociobiol 56:81-88

Lewis S, Grémillet D, Daunt F, Ryan PG, Crawford RJM, Wanless S (2006) Using behavioural variables to identify proximate causes of population change in a seabird. Oecologia $147(4): 606-14$

Mitchell PI, Newton SF, Ratcliffe N, Dunn TE (2004) Seabird populations of Britain and Ireland. TD Poyser

Montevecchi WA (1991) Incidence and types of plastic in gannet nests in the northwest Atlantic. Can J Zool 69: 295-297

Montevecchi WA (2002) Interactions between fisheries and seabirds. In: Schreiber EA, Burger J (eds) Biology of marine birds. CRC Press, Boca Raton, FL, p 527-557

Muus BJ, Dahlström P (1985) Meeresfische der Ostsee, der Nordsee, des Atlantiks. BLV Verlagsgesellschaft, München

Nelson JB (2002) The Atlantic gannet. Fenix Books, Norfolk 
Noodahl K, Korpimaki E (2002) Seasonal changes in the numerical responses of predators to cyclic vole populations. Ecography 25:428-438

Pedersen SL, Ryan PG, Grémillet D (2006) Is food availability limiting African penguins at Boulders? A comparison of foraging effort at mainland and island colonies. Ibis 148:14

Pingree RD, Forster GR \& Morrison GK (1974) Turbulent convergent tidal fronts. J Mar Biol Assoc UK 54:469-479

Primack RB (2000) A primer of conservation biology. Sinauer Associates, Sunderland, MA

Redman KK, Lewis S, Griffiths R, Wanless S, Hamer KC (2002) Sexing northern gannets from DNA, morphology and behavior. Waterbirds 25:230-234

Ryan PG, Petersen S, Peters G, Grémillet, D (2004) GPS tracking a marine predator: the effects of precision, resolution and sampling rate on foraging tracks of African penguins. Mar Biol 145:215-223

Saether BE, Bakke O (2000) Avian life history variation and contribution of demographic traits to the population growth rate. Ecology 81:642-653

Sanz JJ (2002) Climate change and breeding parameters of great and blue tits throughout the western Palaearctic. Global Change Biol 8:409-422

Sims DW, Southall EJ, Tarling GA, Metcalfe JD (2005) Habitatspecific normal and reverse diel vertical migration in the plankton-feeding basking shark. J Anim Ecol 74:755-761

Siorat F (1992) Evolution des effectifs de fou de Bassan, Macareux moine et Puffin des Anglais sur l'archipel des Sept-Iles (Bretagne). Rapport LPO Ministère de l'Environnement

Siorat F (1998) Evolution de la colonie de fous de Bassan, Morus bassanus, de l'Île de Rouzic de 1939-1996. Le Cormoran 47:173-175

Siorat F (2004) Fou de Bassan. In: Cadiou B, Pons JM, Yésou P (eds) Oiseaux marins nicheurs de France métropolitaine (1960-2000). Editions Biotope, Mèze, p 70-73

Siorat F, Rocamora G (1995) Changes in numbers and distribution of the northern gannet (Morus bassanus) on Rouzic Island, (Réserve Naturelle des Sept-Iles, Bretagne), France 1939-1994. Colon Waterbirds 18:172-178

Sokal R, Rohlf FJ (1981) Biometry, 2nd edn. Freeman, New York

Southward AJ, Langmead O, Hardman-Mountford NJ, Aiken

Editorial responsibility: Rory Wilson (Contributing Editor),

Swansea, UK
J and 15 others (2005) Long-term oceanographic and ecological research in the western English Channel. Adv Mar Biol 47:1-105

Stearns SC (1989) Trade-offs in life history evolution. Funct Ecol 3:259-268

Stephens DW, Krebs JR (1986) Foraging theory. Princeton University Press, Princeton, NJ

Tasker ML, Camphuysen CJ, Cooper J, Garthe S, Montevecchi WA, Blaber SJM (2000) The impacts of fishing on marine birds. ICES J Mar Sci 57:531-547

Taylor SS, Leonard ML, Boness DJ (2001) Foraging trip duration increases for Humboldt penguins tagged with recording devices. J Avian Biol 32:369-372

Thompson PM, Ollason JC (2001) Lagged effects of ocean climate change on fulmar population dynamics. Nature 413: 417-420

Ulrich C, Le Gallic B, Dunn MR, Gascuel D (2002) A multispecies multi-fleet bioeconomic simulation model for the English Channel artisanal fisheries. Fish Res (Amst) 58: 379-401

Vieites DR, Nieto-Roman S, Palanca A, Ferrer X, Vences M (2004) European Atlantic: the hottest oil spill hotspot worldwide. Naturwissenschaften 91:535-538

Wanless S, Harris MP, Redman P, Speakman JR (2005a) Low energy values of fish as a probable cause of a major seabird breeding failure in the North Sea. Mar Ecol Prog Ser 294:1-8

Wanless S, Murray S, Harris MP (2005b) The status of northern gannet in Britain and Ireland in 2003-2004. Br Birds 98:280-294

Weavers BW (1992) Seasonal foraging ranges and travels at sea of little blue penguins Eudyptula minor, determined by radiotracking. Emu 91:302-307

Wilson RP, Pütz K, Peters G, Culik BM, Scolaro, JA, Charrassin JB, Ropert-Coudert Y (1997) Long-term attachment of transmitting and recording devices to penguins and others seabirds. Wildl Soc Bull 25:101-106

Wood AG, Naef-Daenzer B, Prince PA, Croxall JP (2000) Quantifying habitat use in satellite-tracked pelagic seabirds: application of kernel estimation to albatross locations. J Avian Biol 31:278-286

Wooller RD, Bradley JS, Croxall JP (1992) Long-term population studies of seabirds. Trends Ecol Evol 7:111-114

Submitted: January 18, 2006; Accepted: April 11, 2006

Proofs received from author(s): July 11, 2006 